pursued should bo supplemented by a systematic survey of blood groups. Among other contributors Mr. Sasanka Sarkar puts forward a proposal for a classification of the nasal elevation index, and Dr. Biren Bonnerjen, profiting by his sojourn in the United States, discusses "Fish-Hooks in North America and their Distribution". We offer the new periodical a cordial wolcome, and wish it a long and prosperous career.

\section{Extension of Electric Power Supplies in U.S.S.R.}

According to "Russia Today" Press Service, the Commissariat of Power Stations of the U.S.S.R. is expending a sum of 1,056 million roubles on this purposo in tho present year, when $882,000 \mathrm{kw}$. will bo added to the capacity of the gonerating plants of the Union. The capacity of the power stations in the Uliraine has been augmented considerably, a notable addition being a $100,000 \mathrm{kw}$. turbino to the Zuyov Station, which is one of the largest in the U.S.S.R. Two large turbines have been added to the Moscow power system and three new heat and power stations are in courso of construction in that city. The power system of the Urals has been augmented by a 50,000 kw. generator at the Contral Urals Station near Sverdlovsk, which brings the enpacity of this station up to $150,000 \mathrm{kw}$. A heat and power plant was recently put into operation at the Kamensk Aluminium Works in the Urals. Work on a large scale is also proceeding on hydro-electric power plants. This includes work on the world's largest power project, the Kuibyshev Hydro-Electric Centro (on the Samara Bend of the Volga), the power plant of which when completed will havo a generating capacity of 3.4 million $\mathrm{kw}$., and the hydro-electric power stations at Uglich and Rybinsk, two further links in the chain of the Greater Volga Project. The Uglich and Rybinsk stations will have a combined capacity of $440,000 \mathrm{kw}$. Construction is in progress on the first underground hydro-electric power station beyond the Arctic Circle, in the district of Kandalaksha, in the Murmansk Province. This station, which will have a capacity of $150,000 \mathrm{kw}$., will be the third power plant in the Soviet Far North. To provide power for the growing non-ferrous metal industry in the Altai Mountains, building has commenced for a generating station of $240,000 \mathrm{kw}$. capacity on the River Irtysh in Kazakhstan.

\section{Precautions against Flooding in the London Tubes}

Is order to protect railway and road transport services from the risks arising from air raids, London Transport, in conjunction with the Ministry of Transport, has undertaken a great programme of emergency work. The Electrical Times of October 19 states that the total cost of the programme, including that already completed at the outbreak of the VIar, will bo about a million pounds. The most difficult part of the problem was how to protect the underground railways from flooding either from the Thames itself or from sewers or water mains where these are in close proximity to stations. There has been already a preliminary inspection of two examples of such protective works, namely, floodgates installed at Waterloo, where the tunnels of the Northern line go under the river, and work which has been done at King's Cross Underground, to guard against flooding from water mains and sewers. When the works are finished, all the stations and sections of line at present closed will bo reopened and journeys on the Underground will bo as safo as in peace time.

Botr tho floodgates installed at Waterloo and Charing Cross stations on the Bakerloo line are electrically operated. They enable the sub-fluvial sections of the lines between these stations to be isolated during an air raid and so the risk of damaging the under-river tunnels is avoided. Similar floodgates are being installed at Waterloo and Strand stations on the Northern line, which also runs under the Thames. Each gate is mado of built-up steel of an overall thickness of thirteon inches and weighs very nearly six tons. In normal open position it is against the headwall of the station platform tunnel, against the tunnol mouth. It is made to slide horizontally into position across the tumnel mouth within a framework of cast iron and can be operated either electrically or by hand. For electrical operation control is by push-button. The gates would resist a force of more than 800 tons, which is sevoral times greater than any possible pressure of water that might have to be borne. The gates on the Bakerloo line were actually closed during each of the threo air raid warnings which marked tho ourbreal of war, tho time taken to close them being less than threo minutes. The gates were designed by W. T. Halcrow, consulting engineer, in conjunction with I,ondon Trßnsport's engineers.

\section{Commercial Irradiation of Food}

IT is now sixty years ngo since it was first dis. covered that bacteria aro killed by exposure to sunlight, and that the bactericidal effect is duo to rays of short wave-length. For medical purposes the use of such ultra-violet rays is now well lnown, but it is not generally known to what extent irradiation is used commercially in the preparation of foodstuffs, and tho engineering devices that are employed for obtaining the ultra-violet rays. Until recently, sterilization of water by ultra-violet radiation has been hampered by the complexity of the equipment available (Elect. Rev., Sept. 23). Recently, Messrs. Hanovia, Ltd., have brought out the now 'Uster' type of sterilizer, which uses a simple straight generating quartz mercury arc tube with a 700.watt loading. This starts automatically by an electronic discharge from activated metal electrodes. One of these units can deal with 600 gallons of -fluid per hour. Mr. Harding, a director of E. Harding and Sons, Birmingham, states that in a bakery he finds that dough which has been subjected to ultra-violet rays during the soven to ten minutes it is mixing not only gives a loaf a better colour, owing to the slight bleaching action of the rays, but also causes a definite improvement in fermentation. Another application of ultra-violet radiation is to determine 